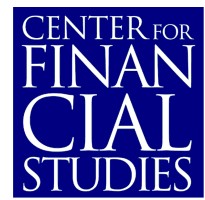

No. $2002 / 08$

\title{
Financing Practices in the German \\ Venture Capital Industry An Empirical Assessment
}

Andreas Bascha and Uwe Walz

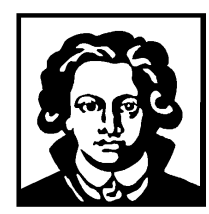


No. $2002 / 08$

Financing Practices in the German Venture Capital Industry An Empirical Assessment

Andreas Bascha and Uwe Walz 

No. $2002 / 08$

Financing Practices in the German

Venture Capital Industry

An Empirical Assessment

Andreas Bascha and Uwe Walz 


\title{
Financing Practices in the German Venture Capital Industry An Empirical Assessment
}

\author{
Andreas Bascha and Uwe Walz*
}

July $2002^{* *}$

\begin{abstract}
:
This paper investigates the financial contracting behavior of German venture capitalists against the results of recent theoretical work on the design of venture capital contracts, especially with regard to the use of convertible securities. First, we identify a special feature of the German market, namely that public-private partnership agencies require significantly lower returns than private and young venture capitalists. The latter are most likely to follow their North-American counterpart by refinancing themselves with closed-end funds. Second, with regard to financing practices it is shown that the use of convertibles, relative to other instruments, is influenced by the anticipated severity of agency problems.
\end{abstract}

JEL Classification: C24; G24; G32

Keywords: Venture Capital; Convertible Securities; Agency Theory

Andreas Bascha, Economic Department, University of Tübingen, Mohlstr. 36, D-72074 Tübingen. Uwe Walz (corresponding author), Economic Department, University of Tübingen, Mohlstr. 36, D-72074 Tübingen, Tel. :+49-7071-29-72962, CEPR, London, UK. and Center for Financial Studies, Taunusanlage 6, D-60329 Frankfurt am Main

** We are very grateful to all participants in the survey, making this study possible. Further, we would like to thank Martin Kukuk and Roman Liesenfeld for their helpful comments on econometric details. Financial support by the Friedrich-List-Stiftung is gratefully acknowledged. 
In the recent past the idea of the important role of venture capital firms in providing financing for start-up companies has been spread to most countries in Continental Europe. This is also due to the fact that it has become widely accepted among academics as well as politicians that venture capital is playing an important role in the development of an economy. ${ }^{1}$

The growing degree of acceptance and the growth of venture capital can be best observed in Germany. Over the last decade the German venture capital industry has left its niche existence and realized high growth rates with regard to funds flowing in. The total volume of funds amounted to 12.81 bill. Euro in 1999 and thereby achieved in this year with $49.6 \%$ one of the highest growth rates throughout the $1990 \mathrm{~s}^{2}$

According to the US role model the typical venture capitalist is characterized by a number of attributes. ${ }^{3}$ First, venture capitalists furnish companies with "active" capital, i.e. besides searching for attractive investments and providing them with funding they get involved into the management of portfolio. Hence, venture capital is also often called "smart money". Second, they provide the capital stage-wise over various financing rounds. Third, for the most part they are organized as closed-end funds which magnifies their desire to invest for only a rather limited period of time and to search for exit channels. Fourth, the data on financing in the US venture capital industry highlights the

1 Kortum/Lerner (2000), for instance, show that in the US much of the growth in patenting appears to have been spurred by the activities of venture capitalists.

2 See BVK (2000).

3 See for an almost classical overview Sahlman (1990). 
dominance of the use of convertible securities such as convertible debt and convertible preferred shares.

In contrast to Germany the long history of venture capital in the US provides for a much broader data base. A growing body of literature, both theoretical and empirical, has evolved over the past two decades and is looking into the details and mechanisms of the North-American venture capital industry. ${ }^{4}$ Because of both data availability and market dominance the vast majority of studies concentrates on the US and Canadian market only. For the German venture capital industry only very few empirical studies exist so far, where appropriate data is almost entirely absent. ${ }^{5}$

Against this background our study aim, with the collection of proper data, to shed further light on specific aspects of the German venture capital market. The study is focused on the financial relationship between the venture capitalists and their portfolio firms, as well as the use of various financial instruments. Thereby, we focus on the above mentioned special characteristic of venture capital contracts, namely the predominance of convertible securities. The ultimate goal of our study is to test whether the broad implications of the hypotheses developed in the theoretical literature on venture capital finance can be confirmed by ar data. ${ }^{6}$ Despite the fact that legal as well as market conditions differ significantly, ${ }^{7}$ this study also addresses the crucial question

4 Rather recently much of the literature has been synthesized in Gompers/Lerner (2000).

5 See for example Schefczyk (1998); Lessat et al. (1999).

6 In order to test explicitly each empirical implication of the various theoretical models on venture capital finance one would need data on the structure of individual venture capital deals. Unfortunately, such data is not available so far.

7 Pfirrmann et al. (1997) provide a comparison of the German and the US venture capital market. 
whether insights gained from the US market are transferable to the now largest market in Continental Europe. ${ }^{8}$

In order to collect the appropriate data we conducted a survey questioning all regular members of the German venture capital association (BVK). This data set then enables us to pursue our objectives. Therefore, our study does not only shed light on a so far empirically neglected research question but also offers a new data set on the $\mathrm{f}$ nancial structure of venture capital deals in Germany. Our results suggest that, as a special feature of the German venture capital market, public-private partnership agencies require significantly lower returns from their investments in portfolio firms. Secondly, private and young venture capitalists are the ones which are most likely to follow the model of the typical relationship between a US venture capital firm and its investors, namely the refinancing of investments by closed-end funds.

With regard to the financing practices of German venture capitalists, it appears that the use of convertible securities is for the most part determined by two broad sets of variables. The first set proxies the extent to which the special exit problem in venture capital finance reinforces traditional control and moral hazard problems. The second set of variables tries to capture the consequences of the specific refinancing situation of German venture capitalists for the design of financial contracts. Broadly speaking, both kinds of variables indicate that it is the severity of agency problems in venture capital finance that is calling for the use of convertible securities. Regarding the importance of convertible securities relative to traditional debt-equity financing, our second result con-

8 The largest venture capital market in Europe is the UK, followed by Germany and France. For details see BVK (2000). 
firms by and large the explanations offered in the theoretical literature. Namely, that the additional features of convertible securities such as state contingent payoff functions (milestones) and the de-coupling of the payoff from the control problem are, relative to debt-equity mixes, much more apt to address the control and incentive problems at the exit stage of a venture capital relationship.

The last important finding to be mentioned indicates that the use of a financing instrument that is very specific to the German market, i.e. silent partnerships, can be explained by return requirements and the anticipated proportion of buy-backs, underlining the role of public-private partnership agencies in Germany.

The paper is organized as follows. In the next section we outline the theoretical literature that analyzes the factors determining the choice of financial instruments in venture capital contracts. For the most part these papers focus on the widespread use of convertible securities. In section 3 our data base is discussed. Section 4 serves to present the descriptive analysis of our data. In section 5 we use statistical and econometric techniques to analyze these data and to identify empirically the factors determining financial choices in the German venture capital industry. In section 6 we provide a brief summary. 
With perfect capital markets, i.e. in the absence of information costs, bankruptcy costs, and taxes, the famous irrelevance result of Miller and Modigliani (1958) holds. Financial structure does not have any impact on firm and investment value. In the real world the assumptions of the Miller/Modigliani world are, however, often violated in a number of ways. Especially, in high-tech start-ups informational asymmetries and bankruptcy costs play an important role. Therefore, on the one hand the possibility of raising external capital may be precluded entirely, ${ }^{9}$ and on the other hand he financial structure can be used to improve the value of firms and investment projects. ${ }^{10}$ Financial economists argue that specialized intermediaries, such as venture capitalists, can address these imperfections in a better way than e.g. banks. Venture capitalists invest in the necessary resources and skills to effectively select firms and to monitor them after the investment has been made. The most important mechanisms that venture capitalists use to monitor their portfolio firms are screening mechanisms (Chan (1983)), control rights e.g. the right to fire the founder (Hellmann (1998), Chan et al. (1990)), and the staging of the investment (Bergemann and Hege (1998)).

However, it is not only the non-monetary aspects of venture capital that are critical to its success. Most notably the existence of incentive problems related to asymmetric information and control, are considered to be the reason for the observed complexity of $\mathbf{f}-$ nancial contracts. The most remarkable feature of financial structure in the NorthAmerican venture capital industry is the unusually broad reliance on convertible securi-

9 See e.g. Greenwald, Stiglitz and Weiss (1984).

10 See e.g. Myers and Majluf (1984). 
ties. Various empirical studies have shown that the percentage of venture capital deals using some sort of convertible securities ranges from 20.9 to 94.5 percent depending on the analyzed data set. ${ }^{11}$ These observations have led researchers to think about potential determinants of financial structure in the venture capital industry, especially with regard to the use of convertible securities.

Compared to traditional financial instruments such as loans, bonds, and equity convertible securities exhibit different structures and economic effects. Convertible securities, i.e. convertible preferred shares and convertible debt, are a mixture of debt and equity and an ex-ante specified call option. ${ }^{12}$ For instance, convertible preferred shares depict a combination of preference shares, which entitle the holder to a fixed claim consisting of the face value of preference shares plus accumulated dividends, and a call option on common stocks of the firm. ${ }^{13}$ This implies that in contrast to debt and equity financing the control and payoff mechanisms associated with convertible securities give room for much more flexibility, e.g. through different state contingencies.

Starting from a set of comparable assumptions, existing theoretical research on the design of financial contracts is based on different aspects of agency theory. These studies can be separated into two broad categories. On the one hand, these models look into the design of optimal incentives during the implementation of the project. On the other hand there are models that focus on the fact that venture capitalists typically invest

11 See e.g. Trester (1998); Kaplan/Stromberg (1999); Cumming (2000).

12 We concentrate in the following on these most widely used two main types of convertible securities.

13 The execution of the call option can be either voluntary or automatic if there are verifiable events (e.g. a ratchet). 
in their portfolio companies only for a limited period of time. ${ }^{14}$ Therefore, conflicts of interest may arise between the two parties over when and how the exit of the venture capitalist should take place. These problems can be addressed ex-ante through the design of the financial contract.

In all these models, moral hazard problems play the decisive role. Moral hazard occurs when the actions of the agent cannot be observed by the principal or cannot be verified by third parties (e.g. courts). In order to achieve the first-best result (or at least a second-best solution) the agent has to be induced - via pecuniary incentives - to act in the interest of the principal. The main idea behind all theoretical analyses in venture capital finance is that in young and fast growing firms a multiple of such moral hazard problems (and sometimes adverse selection problems, too) exist at the same time, and in a variety of forms. These extended moral hazard problems are arguably the reasons for the observed complexity of contracts and the use of highly flexible instruments such as convertible securities. ${ }^{15}$ We now discuss the two classes of models in more detail.

14 There are various reasons for investing only for a limited period of time. The most obvious one is that venture capital firms often refinance themselves via closed-end funds. Another reason is that venture capital firms both want and have to signal the success of their investments. This can only be done credibly if the venture capital firms cashes in its initial investment after a while. Additionally, after a certain period of time, initial investments do no longer fit into the risk profile of the venture capital firm (e.g. when the venture evolves from a startup firm to a more mature investment).

15 If both sides of the relationship are assumed to be risk neutral, as is the case in almost all models on venture capital finance, the optimal solution to the traditional one-sided moral hazard is known to be a straight debt contract. This result comes out of the seminal paper by Harris/Raviv (1979). However, if the agent is risk averse then some sort of equity finance should be used. 


\subsection{Incentives during project implementation}

The first class of models focuses on the implementation period of the portfolio firm's project. Thereby, a number of different situations in which the use of convertible securities seem to be most promising has been singled out. We will outline the most prominent arguments analyzed in the literature.

Typically, venture capitalists are actively involved into the management of the portfolio firm. Hence, a two-sided moral hazard problem (i.e. the entrepreneur as well as the venture capitalist have to be induced to undertake effort) may arise. Due to the disutility of effort the entrepreneur as well as the venture capitalist may not undertake first-best actions in order to enhance the success probability of the project. Recently, it has been shown that such double moral hazard problems can be better addressed by convertible securities than by equity finance. ${ }^{16}$ The more flexible financial security (i.e. convertibles) allows to induce optimal effort on the part of both agents. The basic intuition is that on the one hand, due to the fixed repayment part of the convertible security, the entrepreneur has an incentive to reach, via own effort, payoffs above the fixed repayment level. On the other hand, due to the conversion option, the venture capitalist has a more pronounced incentive to undertake effort with convertibles than with equity finance. The superiority of convertible securities is all the more justified the fiercer the effort problem, and the higher the desired return of the venture capitalist relative to the return of the entire project. ${ }^{17}$ That is, we should expect a heavier reliance on convertible securities (relative to other financial instruments), first when venture capitalists and en-

16 See Repullo/Suarez (1998) and Casamatta (1999). 
trepreneurs are reaching for high goals, i.e. an initial public offering (IPO), second when the management resources of the venture capitalist are scarce, i.e. a high number of portfolio firms, and third a high expected rate of return of the venture capitalist.

A different situation where flexible financial instruments such as convertible securities are again superior to debt-equity contracts arises when the entrepreneur is potentially engaged in window dressing. When capital contributions are staged, entrepreneurs have an incentive to create potentially unjustified positive signals about the success probability of their project in order to improve their refunding. However, if the difference in returns across possible states is very large, e.g. $\mathrm{f}$ an IPO is regarded as a possible exit option, convertible securities prove to be superior to debt-equity contracts. This is due to the fact that the entrepreneur, by manipulating signals, runs the risk that the venture capitalist exercises his conversion option thus allowing him to buy underpriced equity when the development of the firm is most favorable. ${ }^{18}$ Consequently, we expect a more frequent use of convertible securities if capital contributions are staged, i.e. in startup situations, ${ }^{19}$ and if firm value rises in the anticipated outcomes.

17 Note that there is no straight forward correlation between the investment amount, required returns relative to expected project returns and the investment stage. Hence, with regard to this aspect, we get no clear prediction about the severity of agency problems in any specific investment stage.

18 See on this argument Cornelli/Oved (1997).

19 In startup situations investment sums are typically lower than in expansion financing, see e.g. Murray (1999). Hence capital staging is much more common in startup financing. 
Venture capitalists aim at IPOs not only in order to realize high returns but also to build up a reputation for superior venture selection and assistance. ${ }^{20}$ Thereby, with his effort decision the entrepreneur influences both the success probability of the firm and also the expected reputational gains of the venture capitalist. In a way, the moral hazard problem is extended to a second dimension. In this situation, once again, convertible securities prove to have superior incentive properties compared to debt-equity contracts when the difference in monetary returns across possible states is large. ${ }^{21}$ Hence, we expect to observe a more frequent use of convertibles the more often the venture capitalist aims at an IPO.

The last justification for the use of convertibles to be mentioned in this subsection argues that convertible securities are also capable of solving simultaneously moral hazard and adverse selection problems. ${ }^{22}$ The hypothesis states that under certain conditions convertible debt contracts are superior to debt-equity contracts because they allow to distinguish between low and high quality entrepreneurs and, at the same time, to induce them not to pursue too risky project strategies. Therefore, we expect venture capitalists to fall back on convertible securities more often the less established the track record of the entrepreneur, and the higher the discretion of the entrepreneur in choosing more or less risky implementation strategies. Both arguments point into the direction of startup and early stage financing situations.

\footnotetext{
20 See e.g. Black/Gils on (1999); Gompers/Lerner (2000) p. 26.

21 See for details Bascha (2000).

22 See e.g. Gompers (1993).
} 


\subsection{Exit models}

The second class of models is based on the exit problem and the associated conflict of interest between the entrepreneur and the venture capitalist. The principal problem at the exit stage consists in the inability of the two parties to verify outcomes against a third neutral party, e.g. a court, if they have different opinions about how and when the venture capitalist should reacquire the liquidity of his investment. While certain actions or outcomes might be observable, meaning that investors know what the entrepreneur did, the inability to write and enforce contracts that are contingent on particular events makes external financing costly. Many of the models of ownership (Grossman and Hart (1986) and Hart and Moore (1990)) and financing choice (Hart and Moore (1998)) depend on this assumption of incomplete contracting. In the context of venture capital financing an efficient solution of the exit problem is vital both for the development of the whole venture capital market (Black and Gilson (1998)) and for the success of the single investment. So far two models have addressed this topic.

First Bascha and Walz (2000) have highlighted the problem of an efficient choice between an IPO and a trade sale as possible exit channels. Generally, the entrepreneur is very much interested in the control over his firm not only during the implementation phase but also after the venture capitalist's exit as his independence is one of the major reasons for him to found his firm. Therefore, he prefers either an initial public offering or a trade sale as exit channel, depending on whether, in a trade sale, he receives a monetary compensation for his preference for control. The venture capitalist, on the other side, benefits from a strong reputation effect when a successful firm goes public. If, however, the firm turns out to be flying rather low, the venture capitalist might prefer an alternative exit channel, resulting in a possible conflict of interest about the appropriate 
ate exit channel. Convertible securities prove to be financial instruments which are sufficiently flexible, so as to enable the entrepreneur to profit from his control preference, and to allow for the optimal exit strategy to be chosen. ${ }^{23}$ Therefore, we would expect more convertible securities to be used if the venture capitalists takes into account the possibility of an initial public offering as a viable exit channel.

A related argument for the use of convertible securities can be derived fom the problem of efficient allocation of control in the bargaining situation of a trade sale (Berglöf (1994)). Because of control benefits of the entrepreneur and the possibility of asset stripping by the potential buyer in bad states of nature, the entrepreneur should be the bargaining partner in sales negotiations only in good states of nature, and the venture capitalist in bad states of nature. This state contingent allocation of control can always be achieved by setting a debt value such that the entrepreneur will always fail on debt repayment in the bad state of nature. Convertible debt then proves to be superior to debt-equity when, in the good state of nature, the potential buyer brings along efficiency enhancements, say because of his management expertise or synergy effects with his established business.

The crucial assumption behind this result is that the venture capitalist retains his ownership in the acquired firm in order to cash in the efficiency enhancements brought about by the buyer of the firm. However, if in a trade sale the venture capitalist sells along with the entrepreneur, the argument supporting the positive relationship between use of convertibles and frequency of trade sales vanishes. Instead, one would expect the use of a mixture of traditional instruments such as debt and equity.

\footnotetext{
23 See for details Bascha/Walz (2000).
} 
To sum up, the common features of all these models are that convertible securities should be used more often the more pronounced the incentive problems are, i.e. the aspiration of high goals such as IPOs, scarce management resources of the venture capitalist, high monetary return requirements, and a high discretion of the entrepreneur who could either manipulate signals or choose too risky projects. With regard to the severity of incentive problems in the investment stage, the theoretical predictions are not straight forward, but point in the direction of startup financing where the probability of failure is very high, entrepreneurs have an unproven track record and high a managerial discretion in choosing the risk profile of the R\&D strategy. Also, the result that the use of convertibles helps to maximize returns in the case of a trade sale is quite specific to the assumptions of the model.

The objective of our research is twofold as we wish to gain detailed insights into the financial instruments used in the German venture capital industry, and to analyze the determinants of the financial architecture. Since for our purpose no public data sources were available we had to collect the necessary data first. We conducted a full survey including all venture capital firms by sending a questionnaire to all regular members of the German Venture Capital Association (BVK). Rather than asking for data on the individual investments of the venture capital firm, which would have caused both selection problems and very poor participation rates, our questions targeted aggregate financial behavior of the venture capital firms. We distinguished two sets of questions. First, we were interested in some general characteristics like age and number of portfolio 
firms, type of fund organization used (closed funds), the venture capitalists' required return relative to market average (subjective appraisal), and percentages of the venture capitalists' investments in different types of portfolio firms (startup or expansion phase). Second, we asked for the relative frequencies of the various financial instruments in the venture capitalists' investments as well as for the relative importance of different expected exit channels.

We sent the questionnaire to all 121 regular members of the $B V K$ (as of January $\left.1^{\text {st }}, 2000\right)$. In order to increase participation rates we enclosed a pre-paid back-envelope and after four weeks we initiated a second round with letters to non-responding venture capital firms. We ended up with an overall response rate of 59.5\%. The 72 responses included 60 (at least partially) answered questionnaires and 12 negative replies. This left us with an effective particpitaion rate of $49.6 \%$. We completed our data base by collecting general data for all non-responding venture capital firms via the internet, relying on the company information given on the webpage of the BVK and the respective venture capital firms. We looked for the number of financed portfolio firms, the age of the venture capitalist and his status (whether there was an influence of public authorities or not). This data is used later on to test for selection bias in our sample.

\section{$4 \quad$ Descriptive Analysis}

The first of our main objectives is to describe the financial behavior of venture capital firms in the German private equity market. Therefore, we focus on the use of different financial instruments. Against this background, it is crucial to consider the specific aspects of the German commercial law. While portfolio firms organized as public corpo- 
rations can rely on equity and convertible securities, ${ }^{24}$ the law entails a special treatment for portfolio firms organized as private limited companies. While they are not allowed to use convertible debt, ${ }^{25}$ they can make use of equity-type instruments (partnership interests). Other allowed specific financial instruments like participating certificates do not fall into one of our broad categories. In our questionnaire, these instruments are $\dot{n}$ cluded in the category "other financial instruments". Silent partnerships, a debt-like financing instrument, loans and proprietors' loans are independent of the legal form.

We transformed these instruments into the following financial categories and asked for their relative frequencies in the contracts of the respective venture capital firm: i) pure equity ii) convertible securities iii) debt-equity mix iv) silent partnerships v) silent partnerships and debt vi) other instruments. Results are presented in Table $1 .{ }^{26}$

Table 1: Financial instruments used (in percentage points)

\begin{tabular}{|c|c|c|c|c|c|c|}
\hline & $\begin{array}{r}\text { Equity } \\
\text { only }\end{array}$ & $\begin{array}{r}\text { Debt- } \\
\text { Equity } \\
\text { Mix }\end{array}$ & $\begin{array}{r}\text { Convertible } \\
\text { Securities }\end{array}$ & $\begin{array}{r}\text { Silent } \\
\text { Partner- } \\
\text { ships }\end{array}$ & $\begin{array}{r}\text { Silent } \\
\text { Partner- } \\
\text { ships } \\
+ \text { Debt }\end{array}$ & $\begin{array}{r}\text { Other } \\
\text { Financial } \\
\text { Instruments }\end{array}$ \\
\hline Mean & 26.6 & 14.4 & 10.6 & 33.1 & 5.6 & 10.7 \\
\hline Median & 20 & 0 & 0 & 15 & 0 & 0 \\
\hline Maximum & 100 & 100 & 90 & 100 & 88 & 90 \\
\hline Minimum & 0 & 0 & 0 & 0 & 0 & 0 \\
\hline
\end{tabular}

24 See $\S \S 192$ ff Akt Gesetz.

25 See $§ \S 238$ HGB.

26 We constructed these categories with a certain degree of freedom in order to make allowances for the diversity of contractual arrangements. For example, we asked for the average percentage of contracts where convertibles were present, i.e. convertibles only and combinations with other instruments. 
As can be seen from Table 1, the instrument of silent partnerships is the most widely used in the German venture capital industry, followed by pure equity finance, debt-equity mix and convertibles. Overall we obtain a relation of equity to non-equity and other financing instruments of about $51 \%$ to $49 \%$. Statistics provided by BVK (2000) about the financing of new investments in 1999 report this relation $47 \%$ to $50 \%$.

The min. and max. values of table 1 already gives us a first hint that venture capital firms differ in their use of the various instruments. This suspicion is confirmed when looking at the data in more detail. The financial instruments used by the majority of firms are pure equity (70\%) and silent partnerships (63\%). Hwever, there is always a large number of firms that do not use the respective financial instrument at all. ${ }^{27}$ This is especially true for the case of convertible securities (57.41\%) and debt-equity mixes (66.67\%), where even the majority of firms do not apply them. Therefore, in the case of convertible securities a quite different picture emerges compared with the NorthAmerican venture capital industry, where the most part of venture capital contracts are based upon convertibles. ${ }^{28}$ Figure 1 depicts the cumulative distributions of pure equity and convertible securities.

27 This special feature of the data indicates that there might be a threshold effect for the use of the considered financial instrument. We will take this possibility into account by using the Tobit model in our econometric analysis in section 5.2.

28 See e.g. Trester (1998), Kaplan/Stromberg (1999). In fact a new empirical study by Cumming (2000) shows that the use of convertibles is also not that extensive in the Canadian as in the US market. 
Figure 1: Cumulative distribution of financial instruments across venture capital firms
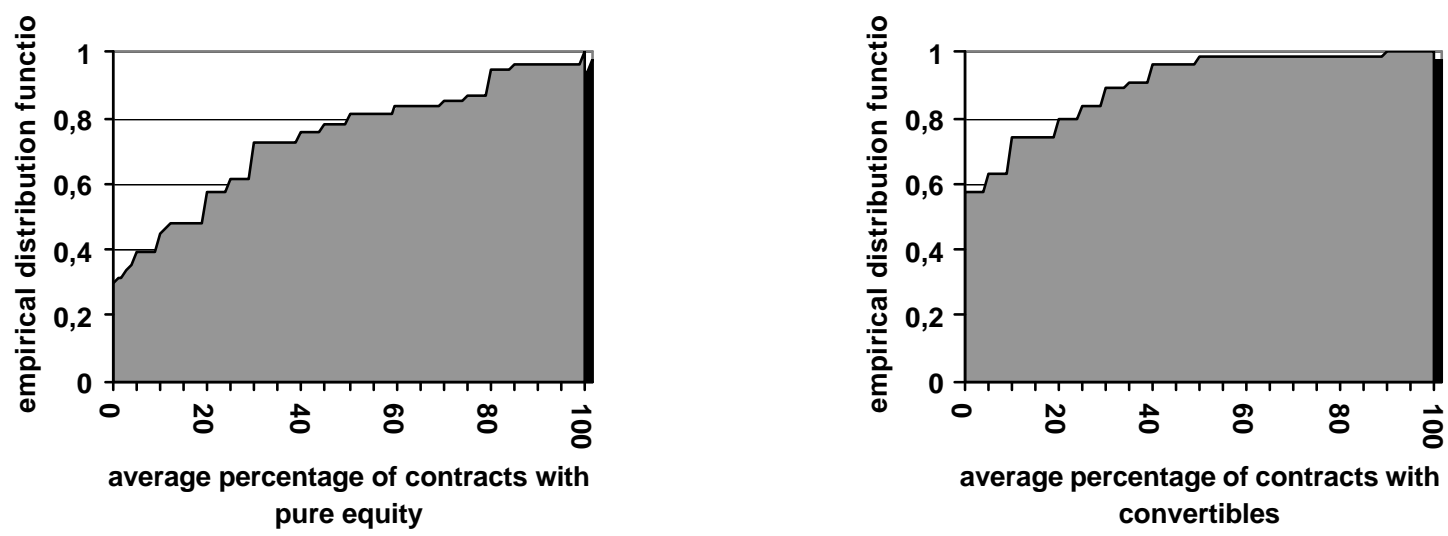

As already pointed out in the previous section, the exit decision is a crucial apect for venture capitalists. Therefore, we will have to investigate the relative importance of different exit channels. The results in Table 2 reflect the responses to our question: What is the expected percentage of an IPO, trade sale, buy-back, liquidation or other alternative as an exit channel from your portfolio companies? This is confronted with the realized values as of $1999 .{ }^{29}$

Table 2: Expected Versus Realized Exit Channels (in percentage points)

IPO Trade Sale Buy-Back Liquidation Other

Realized:

As of 1999

10.1

15.16

35.74

29.78

9.22

Expected:

Mean

27.89

25.23

24.78

9.64

12.4

29 See BVK (2000). 


\begin{tabular}{lccccc}
\hline Maximum & 70 & 100 & 100 & 70 & 100 \\
\hline Minimum & 0 & 0 & 0 & 0 & 0 \\
\hline
\end{tabular}

Expectations are in some contrast with the historical distribution of exit channels in 1999. As venture capitalists like to see POs and trade sales as the role model for an exit, they may have a tendency to anticipate a moving from buy-backs to trade sales and especially IPOs. It is hard to assess, whether these expectations are justified in the sense that with the successful establishment of the German stock-exchange's high-technology segment (Neuer Markt), the relative importance of IPOs will increase in the future. Also, on the side of the entrepreneurs this could reflect a change in their mentality. German entrepreneurs are said to have a strong preference for control over their firms and hence tend to favor a buy-back in order to remain independent. Due to the success story of the "Neuer Markt" this might be changing now. ${ }^{30}$ The important point we want to stress here is that at the contracting stage parties are relying mostly on their expectations in order to structure their financial relationship. A more general problem concerns the reporting of liquidations. Given the high risk of failure in this market and the historical $29.78 \%$, we feel that our number of about $10 \%$ is too low and hence expectations are too optimistic. We will take this problem into account in the next section.

From our theoretical considerations it follows that, the degree of uncertainty and risk involved might be crucial. Therefore, the stage of investment is potentially decisive for the financial structure. We asked for the percentage of portfolio firms being in the startup or expansion phase. It turns out that the average of the share of portfolio firms in

30 The attitudes of both venture capitalists and entrepreneurs towards an IPO very much vary over time
as there are times of hot and cold issue markets. See Gompers/Lerner (2000), chapter 11 . 
the startup stage is $36.9 \%$, whereas it amounts to $59.8 \%$ for the expansion period. ${ }^{31} \mathrm{Gi}-$ ven the recent trend to invest in .com startups, these figures are not that far from the 1999 figures of the BVK reporting $31.2 \%$ and $44.8 \%$ respectively.

Finally, we collected some general data, reflecting age and status of the venture capitalist as well as the number of firms in their portfolios. With respect to the status of the venture capitalist we aimed at capturing an important feature of the German market. Using the membership list of the BVK we characterize a venture capitalist as being public if the ownership structure indicates that there might be an influence of public authorities either directly or indirectly. ${ }^{32} \mathrm{We}$ otherwise define the respective venture capitalist as being private. In the first case we set the PUBLIC variable equal to 1 and in the second case equal to 0 . We thus find $43 \%$ of venture capitalists to be public. This corresponds very well to the findings of Schefczyk (2000) where it is shown that $38 \%$ of all venture capital firms were either public co-investment companies (e.g. KFW and TBG), investment companies for medium-sized firms (Mittelständische Beteiligungsgesellschaften) or saving/regional banks (Sparkassen, Landesbanken).

The data on the variable AGE reflects the fact that the majority of venture capital firms is rather young (50\% of the firms have been established in the last decade). Only few old firms exist and the mean age is 14.4 years, which mirrors the youth of the German market. ${ }^{33}$ Figure 2 additionally shows the size profile of the venture capitalists

31 The remaining part (the two figures do not add up to 100 percent) is in other phases of the investment cycle, e.g. seed, turnaround and buyout stages.

32 Banks or finance institutes mainly controlled by public authorities are very often interested in the promotion of regional business structures and employment.

33 With respect to the characterization of very old firms one has to be careful. First, there are some international players, that have been engaged in the German market for a typically much shorter time. Second, some firms have been active in another industry before entering the venture capital business. 
portfolios. This distribution is highly skewed because only a few venture capitalists are managing a large number of portfolio firms. There are 11 venture capitalists having invested in 100 or more portfolio companies, of which are 8 public and 3 private. This highlights once again the important role of public companies in the German market.

Figure 2: Age of venture capitalists and number of firms in their portfolio
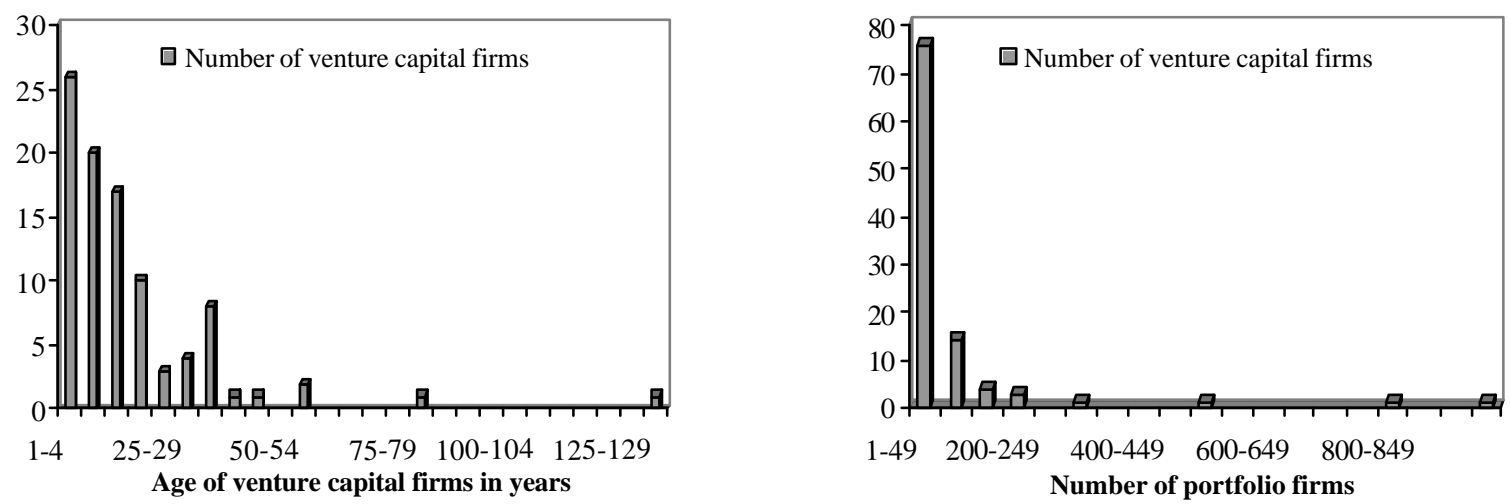

5

Determinants of (Financial) Structures in the German Venture Capital Industry

In this section we turn to our second goal, namely the analysis of the financial contract design between venture capitalists and portfolio firms.

\subsection{General structure}

In order to obtain information about return claims we asked whether the venture capitalist's return claim is below, above, or at the industry's average. These self-assessed $\alpha$ derings do not serve to measure proven performance but intend to reflect the available information at the contracting stage. Since the RETURN variable is a qualitative one 
with three categories we estimate an ordered probit model with AGE, PUBLIC and the NUMBER of portfolio firms as explanatory variables. Results are displayed in Table 3. We find a negative and highly significant effect of PUBLIC on the relative return claims. The effects of the other variables are, however, insignificant. ${ }^{34}$ That is, our data shows a significant difference between private and public venture capitalists in the sense that public firms have lower return claims than private ones.

Table 3: Ordered Probit Estimates for Relative Return Claims

Dependent Variable RETURN

\begin{tabular}{lcc}
\hline Explanatory Variable & Estimated Coefficient & P-Value \\
\hline PUBLIC & -2.133051 & 0.0000 \\
\hline NUMBER & 0.000300 & 0.7744 \\
\hline AGE & -0.000712 & 0.9656 \\
\hline
\end{tabular}

Number of observations: 59 , Pseudo- $\mathrm{R}^{2}=0.267$.

34 The p-value represents, broadly speaking, the probability that the null of $\beta=0$ is true. Hence, e.g. for a p-value of 0.05 the estimated influence of a certain parameter is said to be significant at a $5 \%$ level. 
Our theoretical discussion showed the exit problem to be a decisive factor in the design of financial structure. This exit problem is aggravated if the venture capital firm itself is financed via a closed-end fund. The respective information is the binary variable CLOSED, equal to 1 if the form of closed-end funds is used and 0 otherwise. From an economic point of view, closed-end funds can reduce the agency problems between the venture capital firm and the investor. For example, venture capitalists do not want to terminate their investments in poorly performing firms in due time because of the associated reputation losses. Therefore, one would expect this organizational form to be most common with private and young venture capitalists investing mainly in startup companies, where agency problems of this kind are potentially the highest. This is confirmed by the data. A binary probit estimation, see Table 4 reveals that PUBLIC and AGE have a significant impact on the use of closed-end funds. That is, in line with Zemke (1995) venture capitalists being private, young are most likely to follow the typical relationship between a North-American venture capital firm and its investors.

Table 4: Binary Probit Estimation for the Use of Closed-End Funds

Dependent Variable CLOSED

\begin{tabular}{lcc}
\hline Explanatory Variable & Estimated Coefficient & P-Value \\
\hline CONST & 0.525984 & 0.3042 \\
\hline PUBLIC & -1.361245 & 0.0031 \\
\hline AGE & -0.060653 & 0.0560 \\
\hline STARTUP & 0.004033 & 0.5447 \\
\hline NUMBER & -0.001159 & 0.6881
\end{tabular}

Number of observations: 57 , Mc-Fadden $\mathrm{R}^{2}=0.28$ 
The last problem to be addressed in this section concerns the question of whether the results of our survey are representative for the whole German venture capital industry. As our data base contains information on the variables AGE, NUMBER and PUBLIC for all responding as well as non-responding venture capitalists, we are able to test for a selection bias in our data. For this purpose we run a binary probit estimation for RESPONSE, which takes the value 1 if a response occurred and 0 otherwise. As summarized in Table 5 the explanatory power of AGE and NUMBER is very low. Only for the status of the venture capital firms it turns out that the probability for answering to the questionnaire is slightly higher for public firms at a 5\% level. Additionally, the Mc-Fadden $\mathrm{R}^{2}$ for this estimation is very low. Hence, with regard to the generalizability of our results we consider the possibility of a selection bias only as a minor problem.

Table 5: Estimates for Selection Bias

\begin{tabular}{lcc}
\hline Dependent Variable RESPONSE & & \\
\hline Explanatory Variable & Estimated Coefficient & P-Value \\
\hline CONST & 0.611769 & 0.0116 \\
\hline PUBLIC & 0.738647 & 0.0300 \\
\hline AGE & 0.001171 & 0.5905 \\
\hline NUMBER & -0.014514 & 0.1672
\end{tabular}

Number of observations: 87 , Mc-Fadden $\mathrm{R}^{2}=0.1$

\subsection{Financial Structure}

Since our focus is on financial instruments, and especially convertible securities, we now investigate the extent to which they are used. For that purpose we use for the most part of our estimations the censored regression model, or the Tobit model. The necessity for this methodology is born of the special characteristic of our data, namely that there is always a large number of venture capital firms in our sample that do not use the e- 
spective financial instrument. This feature destroys the linearity assumption so that the usual linear regression model is inappropriate. Technically speaking, the sampling distributions are a mixture of discrete and continuous distributions. The econometrically adequate method to address this problem is to use the following Tobit model, ${ }^{35}$

$$
\begin{gathered}
y_{i}^{*}=x_{i}^{\prime} \beta+\varepsilon_{i} \\
\text { and } \\
y_{i}=\left\{\begin{array}{lll}
0 & \text { if } & y_{i}^{*} \leq 0 \\
y_{i}^{*} & \text { if } & y_{i}^{*}>0
\end{array}\right.
\end{gathered}
$$

whereby (1) is the latent variable regression model of the dependent variable. There, $y_{i}^{*}$ is the solution of a decision problem without a boundary constraint that allows only for non-negative solutions. What does this mean in our context? Venture capital contracts are designed to solve agency problems of a certain extent, with the help of specific $\mathbf{f}-$ nancial instruments. Theoretical considerations have shown that as the severity of agency problems increases, one has to switch from traditional financing instruments like debt and equity to more complicated ones. In other words, there seems to be a certain threshold of agency problems from then on one uses high incentive instruments like convertible securities. Therefore, if one tries to estimate the determinants of the use of a certain financial instrument, the solution to the properly specified problem can be defined by (2), which describes the transformation rule of the original variable into the new random variable $y_{i} . x_{i}^{\prime}$ denotes the vector of explanatory variables that influence the degree of agency problems faced by each venture capitalist.

35 See e.g. Amemiya (1985), chapter 10. 
In the set of explanatory variables we include IPO (+), TRADE SALE (+,-), BUY-BACK (-), EXPANSION (+,-), CLOSED (+), RETHIGH (+), RETMEAN (+,-), with the signs in the brackets representing our expectations of the variables' influence on the perceived extent of agency problems. As one can see, we thereby break down the RETURN variable into separate binary variables RETHIGH, RETMEAN, RETLOW which take the value of 1 if the answer in the questionnaire occurred in the respective category and 0 otherwise. ${ }^{36}$ We utilize AGE and NUMBER as additional control variables. Hence, we choose to disregard LIQUIDATION, STARTUP, RETLOW, and PUBLIC as explanatory variables. This is because the LIQUIDATION, STARTUP, and RETLOW are residual variables for the exit, stage, and return questions. With regard to PUBLIC a high correlation with RETURN has occurred in Table 3. Hence, only one of them should be included in the same set of explanatory variables.

The first step is a Tobit analysis (based on the standard normal distribution) of $\mathrm{CS}$, which denotes the importance of convertible securities in percentage points given as an average over all contracts of a single venture capitalist. Results are stated in Table 6 .

Table 6: Tobit Estimation on the Use of Convertible Securities

\begin{tabular}{lcc}
\hline Dependent Variable CS & & \\
\hline Explanatory Variable & Estimated Coefficient & P-Value \\
\hline CONST & -22.00753 & 0.1953 \\
\hline IPO & 0.470047 & 0.0089 \\
\hline TRADE SALE & -0.389272 & 0.0897 \\
\hline
\end{tabular}

36 This avoids the problematic interpretation of an ordinal explanatory variable on the right hand side. See Greene (1990), p. 234 for the problem of threshold effects in this context. 


\begin{tabular}{lll}
\hline BUY-BACK & -0.165778 & 0.4800 \\
\hline EXPANSION & -0.073275 & 0.5527 \\
\hline CLOSED & 7.966538 & 0.3489 \\
\hline RETHIGH & 46.74868 & 0.0015 \\
\hline RETMEAN & 22.52156 & 0.0451 \\
\hline AGE & 1.104376 & 0.0182 \\
\hline NUMBER & -0.149694 & 0.2541 \\
\hline
\end{tabular}

Number of observations: 47 , adjusted $\mathrm{R}^{2}=0.51$

All significant agency variables can be interpreted in line with our theoretical considerations. Most importantly the higher the expected amount of IPOs, the more pressing is the exit problem and the higher the effort required from both agents. This effect is also very robust against the variation of the assumed underlying distribution function. In a regression that controls for robust standard errors and covariance (Huber/White) IPO is the only variable that remains significant at the $5 \%$ level.

The negative influence of TRADE SALE is only significant at the $10 \%$ level. This finding could be interpreted as slight evidence for the argument that the expected frequency of IPOs and trade sales have different effects on the anticipated severity of agency problems calling for a more or less extensive use of convertible securities. We will investigate this argument in the next estimation on the relation between convertible securities and debt/equity financing in greater detail.

Further, it turns out that venture capital firms with high return claims use convertible securities, with their flexible incentive and control mechanisms, significantly more often. This result favors on the one side the double moral hazard models and indicates on the other side that public-private partnership agencies face a lower pressure to 
solve agency problems because of their moderate return requirements. We regard this as a major explanation for the quantitatively lower importance of convertibles in Germany. The last significant variable AGE can also be interpreted in the light of the special structure of the German venture capital market. As a matter of fact older venture capitalists have more experience with regard to this special kind of financial instrument. Additionally, the international players on the German market are both much older than originally German venture capital firms and much more familiar with convertibles.

For the most part the theoretical models explain the superiority of convertible securities over traditional financing instruments such as debt-equity mixes as a benchmark case. Though debt-equity mixes have a certain flexibility in payoff structures, and include the possibility of a control change, the additional features of convertible securities such as state contingent payoff functions (milestones) and the de-coupling of the payoff from the control problem are much more apt to deal with the complexity of agency problems in venture capital finance. For example, the conversion option can either widen the spread in payoffs leading to improved incentives or transfer control rights even in good states of nature. Both effects are not available under debt-equity mixes. However, since these instruments are quite closely interrelated, it is sensible to compare them with each other and to analyze the features making one or the other more attractive. For that reason we compute the difference between the two variables convertible securities (CS) and debt-equity mixes (DE) and call this new variable CSDE. As this new variable ranges from $-100 \%$ to $+100 \%$ the problem with a large number of zero observations at the sides of the distribution is avoided. Hence, we are able to perform an ordinary-least-squares regression. The results are reported in Table 7. 
Table 7:Ordinary-Least-Squares Estimation for the Difference between Convertibles and Debt-Equity Mix

Dependent Variable CSDE

\begin{tabular}{lcc}
\hline Explanatory Variable & Estimated Coefficient & P-Value \\
\hline CONST & 0.360767 & 0.9816 \\
\hline IPO & 0.463478 & 0.0473 \\
\hline TRADE SALE & -1.012117 & 0.0014 \\
\hline BUY-BACK & 0.007762 & 0.9672 \\
\hline EXPANSION & -0.059985 & 0.7017 \\
\hline CLOSED & -10.88889 & 0.3440 \\
\hline RETHIGH & 18.04575 & 0.3267 \\
\hline RETMEAN & 14.45264 & 0.2575 \\
\hline AGE & 0.695995 & 0.1972 \\
\hline NUMBER & -0.022024 & 0.5275 \\
\hline NUmber of ind & &
\end{tabular}

Number of included observations: 47 , adjusted $R^{2}=0.24$.

The only two significant variables are IPO (5\% level) and TRADE SALE (1\% level). This supports the theoretical hypothesis that mainly the anticipated agency problems, stemming from the exit problem, drive the decision whether to use convertible securities or traditional debt-equity mixes. If IPOs are the preferred exit channel this seems reasonable because, as it is argued by Bascha and Walz (2000), the potential conflict of interest between the two parties with respect to the efficient choice of the exit mode, can only be solved by the use of a financial instrument that allows both for a conditional switch in payoff structures and a contingent allocation of control rights. Contrary to that, if the bargaining problems associated with trade sales are expected to dominate at the exit stage, the use of convertibles are not really necessary if the venture capitalist sells together with the entrepreneur (see Berglöf (1994)). In this case it suf- 
fices to use a debt/equity mix in order to allocate control rights efficiently between the two parties.

Next, we take a closer look at the two remaining categories in venture capital finance: equity and silent partnerships. As outlined in the previous section, these instruments are employed by the majority of venture capitalists. For both variables we run the same Tobit estimation as for CS before.

The results are displayed in Table 8 and Table 9.

Table 8: Tobit Estimation for the Percentage of Equity used

Dependent Variable EQUITY

\begin{tabular}{lcc}
\hline Explanatory Variable & Estimated Coefficient & P-Value \\
\hline CONST & -12.17049 & 0.4800 \\
\hline IPO & 0.260096 & 0.2522 \\
\hline TRADE SALE & 0.070897 & 0.8129 \\
\hline BUY-BACK & -0.184656 & 0.4135 \\
\hline EXPANSION & & 0.2330 \\
\hline CLOSED & 0.192387 & 0.7889 \\
\hline RETHIGH & -3.035397 & 0.3557 \\
\hline RETMEAN & 17.14406 & 0.0018 \\
\hline AGE & 40.36616 & 0.4653 \\
\hline NUMBER & -0.419376 & 0.5291
\end{tabular}

Number of observations: 47 , adjusted $\mathrm{R}^{2}=0.22$ 
There are no significant variables other than RETMEAN, indicating that the use of equity finance alone is not influenced by our proxies for the severity of agency problems. Further, the significance of RETMEAN supports the interpretation that pure equity finance is the most suitable instrument for the financing of average portfolio firms showing a normal degree of agency problems. Using equity finance the venture capitalist both becomes a residual claimant to the returns of the project, which enhances his incentives to provide effort to the project, and receives control and information rights in order to monitor the firm. Together with the results from above this confirms the point of view that the incentive properties and the complexity of the chosen financial structure varies positively with the anticipated degree of incentive and control problems faced by the contracting parties. This relates also to the following results of Table 9.

There, we aggregate silent partnerships and debt to form the variable SILENTDEBT. According to the theory of traditional moral hazard, the use of silent partnerships and debt should be most prominent if it suffices to provide the (risk neutral) entrepreneur with the right incentives (Harris/Raviv (1979)). That is on the side of the venture capitalist, for a low degree of control and monitoring problems, and a minor importance of the exit problem. For example, if the venture capitalist does not aim at an IPO, he is not refinanced by a closed-end fund and his return requirement is below market average. Additionally, entrepreneurs who aim at a buy-back and are reluctant to share control over their firm prefer debt-like financing instruments over equity finance. Also, with debt finance venture capitalists get a sufficiently hard claim in order to enforce their payoff rights in the case of a buy-back. 
Table 9: Tobit Estimation on the Use of Silent Partnerships and Debt

\begin{tabular}{lcc}
\hline Dependent Variable SILENTDEBT & & \\
\hline Explanatory Variable & Estimated Coefficient & P-Value \\
\hline CONST & 76.84001 & 0.0000 \\
\hline IPO & -0.595809 & 0.0162 \\
\hline TRADE SALE & -0.122496 & 0.6757 \\
\hline BUY-BACK & 0.355371 & 0.0247 \\
\hline EXPANSION & -0.046739 & 0.7552 \\
\hline CLOSED & -41.16246 & 0.0010 \\
\hline RETHIGH & -62.61049 & 0.0038 \\
\hline RETMEAN & -38.29968 & 0.0006 \\
\hline AGE & -0.024771 & 0.9576 \\
\hline NUMBER & 0.010978 & 0.7034
\end{tabular}

Number of observations: 47 , adjusted $\mathrm{R}^{2}=0.70$

All significant effects are completely in line with theory. Most notably, we find a significant and negative effect for initial public offerings and a positive effect of the buy-back alternative as exit route on the choice of debt-like financing instruments by German venture capitalists. Together with the negative effects of CLOSED, RETHIGH and RETMEAN respectively it becomes quite obvious that silent partnerships and debt financing is most often used if the venture capitalist does not care much about the incentive and control aspects of the exit problem and not exclusively aims at maximizing the returns from investments. In this context one could argue that public-private-partnership agencies are traditionally supporting the financing of startups and medium-sized firms by publicly guaranteed loans in order to promote regional development. As they do not face the same extent of agency problems as private venture capitalists, they are more likely to use rather low powered incentive compatible financing instruments such as 
debt and silent partnerships. The latter instruments seem to have evolved along with the tradition of independent entrepreneurs and the handing-over of family-owned businesses from one generation to the other. The special role played by public-private partnerships in the German market might reinforce the constancy of this tradition.

\section{Summary}

In this paper we have analyzed some important structures in venture capital finance. Our analysis thereby shed some light on the details of the corporate control mechanisms in the German venture capital industr. Our survey data have allowed us to explore general characteristics of the industry and especially the relative importance of different financial instruments. Additionally, we were able to test the broad implications of theoretically derived hypotheses on the determinants of the financial structures in venture capital contracts.

With respect to general characteristics, we have detected that private venture capitalists tend to have higher return claims than public ones. Also private and young venture capitalist organize their refunding more often by means of closed-end funds. This indicates that with regard to the perceived extend of agency problems there may be a significant difference between private venture capitalists and public-private-partnership agencies. The quantitative and qualitative importance of public actors in the German market may be one of the causes for the relative low frequency of convertibles and the dominance of silent partnerships as financial instruments. It would be interesting to see if this influence could also be supported on an European level. 
Our results with respect to the determinants of the chosen financial structure are in line with the theoretical hypotheses derived in the literature. We find that in cases when venture capitalists expect a high frequency of IPOs as a exit channel they are more inclined to use the more complex and flexible financial securities, especially convertible securities. Higher return claims and the use of closed-end funds make the use of these instruments more likely, too. This indicates that the use of convertibles (relative to other instruments) is influenced by the severity of agency problems. Accordingly, debtlike financing instruments like silent partnerships tend to be chosen when agency problems are low and the venture capitalist expects a high frequency of buy-backs.

Obviously there are many questions we were not able to address with this particular kind of data. The most important shortcoming is the lack of a detailed data base on the level of the individual contractual relationship between the venture capital firm and the entrepreneur. Overcoming this problem would allow us to test the various theories about the choice of the financial structure more directly and is, without doubt, one of the main objectives of our future research. 


\section{Literature}

Bascha, Andreas (2000), Why do Venture Capitalists hold different types of equity $\mathbf{e}$ curities?, Working Paper, University of Tuebingen.

Bascha, Andreas/Walz, Uwe (2000), Convertible Securities and Optimal Exit Decisions in Venture Capital Finance, Journal of Corporate Finance, forthcoming.

Berglöf, Erik (1994), A control theory of venture capital finance, Journal of Law, Economics and Organisation 10: 247-267.

Bergemann, Dir/Hege, Ulrich (1998), Dynamic venture capital financing, learning and moral hazard, Journal of Banking and Finance 22: 703-735.

Black, Bernard S./Gilson, Ronald J. (1999), Venture capital and the structure of capital markets: Banks versus stock markets, Journal of Financial Economics 47: 243-277.

BVK (2000), Bundesverband Deutscher Kapitalbeteiligungsgesellschaften, Yearbook.

Casamatta, Catherine (1999), Financing and Advising: Optimal financial contracts with venture capitalists, Working Paper.

Chan, Yuk-Shee (1983), On the positive role of financial intermediation in allocation of venture capital in a market with imperfect information, Journal of Finance 38: 15431568.

Chan, Yuk-Shee/ Siegel, Daniel R./Thakor, Anjan V. (1990), Learning, corporate control and performance requirements in venture capital contracts, International Economic Review 9: 38-51.

Cornelli, Francesca/Oved, Yosha (1997), Stage financing and the role of convertible debt, CEPR discussion paper series, No. 1735. 
Cumming, Douglas J. (2000), The convertible preferred equity puzzle in venture capital finance, Working Paper.

Gompers, Paul A. (1993), The theory, structure and performance of venture capital.

Gompers, Paul A./Lerner, Josh (2000), The Venture Capital Cycle.

Greene, William H. (1990), Econometric Analysis, Second Edition, Prentice Hall.

Greenwald, Bruce C./Stiglitz, Joseph E./Weiss, Andrew (1984), Information imperfections in the capital market and macroeconomic fluctuations, American Economic Review Papers and Proceedings 74: 194-199.

Grossman, Sanford/Hart, Oliver D. (1986), The costs and benefits of ownership: A theory of vertical and lateral integration, Journal of Political Economy 94: 691-719.

Harris, Milton/Raviv, Artur (1979), Optimal incentive contracts with imperfect information, Journal of Economic Theory 20: 231-259.

Hart, Oliver D./Moore, John (1990), Property rights and the nature of the firm, Journal of Political Economy 98: 1119-1158.

Hart, Oliver D./Moore, John (1998), Default and renegotiation: A dynamic model of debt, Quarterly Journal of Economics 113: 1-41.

Hellmann, Thomas F. (1998), The allocation of control rights in venture capital contracts, Rand Journal of Economics 29: 57-76.

Kaplan, Steven N./Stromberg, Per (1999), Financial contracting theory meets the real world: An empirical analysis of venture capital contracts, CEPR discussion paper $\mathscr{e}$ ries, No. 2421. 
Kortum, Samuel/Lerner, Josh (2000), Assessing the contribution of venture capital to innovation, RAND Journal of Economics, forthcoming.

Lessat, Vera et al. (1999), Beteiligungskapital und technologieorientierte Unternehmensgründungen.

Myers, Stewart C/Majluf, Nicholas S. (1984), Corporate Financing and Investment Decisions When Firms Have Information That Investors Do Not Have, Journal of Financial Economics 13: 187-221.

Modigliani, Franco/Miller, Merton H. (1958), The Cost of Capital, Corporation Finance and the Theory of Investment, American Economic Review 48: 261-297.

Murray, Gordon (1999), Early-Stage Venture Capital Funds, Scale Economies and Public Support, Venture Capital 1: 351-384.

Pfirrmann, Oliver/Wupperfeld, Udo/Lerner, Joshua (1997), Venture Capital and New Technology Based Firms.

Repullo, Rafael/Suarez, Javier (1998), Venture capital finance: A security design approach, CEMFI working paper, No. 9804.

Sahlman, William A. (1990), The Structure and Governance of Venture Capital Organizations, Journal of Financial Economics 27: 473-521.

Trester, Jeffrey J. (1998), Venture capital contracting under asymmetric information, Journal of Banking and Finance 22: 675-699.

Schefzyk, Michael (1998), Erfolgsstrategien Deutscher Venture Capital Gesellschaften.

Schefzyk, Michael (2000), Finanzieren mit Venture Capital.

Zemke (1995) Die Unternehmensverfassung von Beteiligungskapital-Gesellschaften. 


\section{CFS Working Paper Series:}

\begin{tabular}{ll} 
No. & Author(s) \\
\hline $2001 / 11$ & Daniel Gross \\
$2001 / 12$ & Daniel Gross \\
& \\
$2002 / 01$ & $\begin{array}{l}\text { Stefan Feinendegen } \\
\text { Daniel Schmidt } \\
\text { Mark Wahrenburg }\end{array}$ \\
\hline
\end{tabular}

2002/02 Issam Hallak

2002/03 Raimond Maurer Christian Schlag

2002/04 Holger Claessen Stefan Mittnik

2002/05 Bernd Kaltenhäuser

2002/06 Erik Theissen

2002/07 Werner Neus Uwe Walz

2002/08 Andreas Bascha Uwe Walz
Title

Country-Specific and Global Shocks in the Business Cycle

Trade Flows and the International Business Cycle

Die Vertragsbeziehung zwischen Investoren und Venture Capital-Fonds: Eine empirische Untersuchung des europäischen Venture Capital-Marktes

Price Discrimination on Syndicated Loans and the Number of Lenders: Empirical Evidence from the Sovereign Debt Syndication

Money-Back Guarantees in Individual Pension Accounts: Evidence from the German Pension Reform

Forecasting Stock Market Volatility and the Informational Efficiency of the DAX-index Options Market

Return and Volatility Spillovers to Industry Returns: Does EMU Play a Role?

Internalisierung und Marktqualität:

Was bringt Xetra Best?

Exit Timing of Venture Capitalists in the Course of an Initial Public Offering

Financing Practices in the German Venture

Capital Industry

An Empirical Assessment

Copies of working papers are available at the Center for Financial Studies or can be downloaded (http://www.ifk-cfs.de). 